\title{
FORESTRY EDUCATION IN THE UNIVERSITY OF TORONTO
}

\author{
By G. G. Cosens
}

Faculty of Forestry, University of Toronto, Toronto, Ontario.

Some time prior to the cessation of hostilities a number of committees were formed in the University of Toronto. The Senate, the Governors and the teaching staff were represented on these committees which had as their objective a study of the problems presented by demobilization. Policies were formulated and an attempt was made to estimate the approximate number of students who would seek registration in the various faculties and schools.

The general opinions expressed in these preliminary discussions were that there was a great opportunity to enroll a superb student body and that every effort should be made to give these men and women university training. Any lowering of academic standards was to be deplored and any undue encouragement to the academically weak was not to be considered a kindness. Minimum standards for class room and laboratory facilities in the science courses and professional schools were set at a level at least equal to those normally provided.

In the Faculty of Forestry the problems were three: curriculum, laboratory and lecture space, and adequate accommodation while on feld work.

The curriculum was adjusted slightly in the first two years taking into account the difficulties confronting men returning to scholastic work after a considerable lapse of time. The requirements of the third and fourth years remained essentially the same.

The seating capacity of existing laboratories and lecture rooms was in. creased and two new laboratories and a major lecture room added. With these additions and by freezing a time-table developed during the 1944.45 session it was considered possible to take large classes.

Fortuitously, the Ontario Department of Lands and Forests ranger school buildings, located on the University Forest in Haliburton, had progressed to the stage where temporary accommodation would be available during the spring field work for incoming freshmen and probably. for subsequent first and second year classes.

A complete survey of available and new accommodation which was a part of a general university review fixed the maximum number of freshmen that could be accommodated at 100 . In estimating subsequent enrolment in the second, third and fourth years the average failure rate over the past thirty. five years was used as a basis. Present indications are that these estimates were wrong. Instead of an anticipated degree of restlessness and lack of application to work the opposite has proved to be the case. The returned men are 
hard, earnest workers and it is expected that the failure rate will be lower than estimated so that upper year crowding would seem to be inevitable.

In the University of Toronto freshmen classes are admitted to all courses by the Registrar's office and special cases are dealt with by an admittance committee. When it became apparent that the numbers seeking to enroll were much beyond the accommodation provided this committee assumed responsibility for selection. The general rules of procedure laid down by the Council of the Faculty in selecting first year students were,-

1. High school and service men to be separated. Less than eight months service to be considered as high school. That is, for the purpose of defining service eight months to be considered the minimum.

2. Approximately fifteen men to be selected from high school applications on the basis of scholarship. Some attention to be given to the origin of the applicant to obtain as wide a provincial distribution as possible.

3. Service men to be ranked on the basis of academic standing. In final selection preference to be given to length of service.

4. No incomplete applications to be given consideration and no application received after 1 September to be considered.

Applying this system of selection 115 students were admitted to the first year at the opening of the 1946-47 session.

\begin{tabular}{|c|c|c|c|}
\hline & Number & Number & $\begin{array}{c}\text { Total } \\
\text { Annlications }\end{array}$ \\
\hline $\begin{array}{l}\text { Ex-service candidates } \\
\text { ith } 36 \text { months service and over }\end{array}$ & $\begin{array}{c}\text { Rejected } \\
20\end{array}$ & $\begin{array}{c}\text { Accepted } \\
56\end{array}$ & $\begin{array}{l}\text { Applications } \\
76\end{array}$ \\
\hline ith less than 36 months service ..... & 51 & 47 & 98 \\
\hline complete, miscellaneous, etc. & 51 & - & 51 \\
\hline Civilian candidates... & 33 & 12 & 45 \\
\hline Totals & 155 & 115 & 270 \\
\hline
\end{tabular}

The total registration in the Faculty for 1946.47 is,--

\begin{tabular}{|c|c|c|}
\hline & Ex-service & Civilian \\
\hline First Year & 103 & 12 \\
\hline Second Year & 77 & 15 \\
\hline Third Year & 26 & 13 \\
\hline Fourth Year ......... & 7 & 13 \\
\hline Totals & 213 & 53 \\
\hline
\end{tabular}

A Forestry student's training at the University of Toronto is divided into lecture, laboratory and field work. Selected courses are given by the Faculties of Arts and Applied Science and Engineering. The ,work is apportioned on a percentage basis as follows,- 


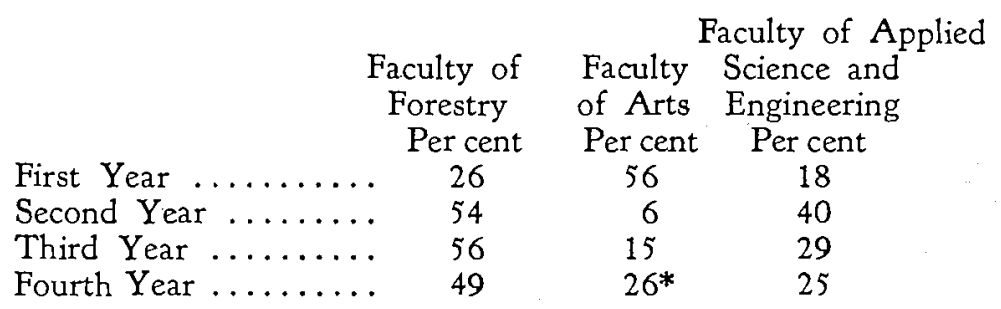

In addition, First, Second and Third Years spend three weeks in field work at the University Forest; and Fourth Year spends one week at the Provincial Forest Station at St. Williams.

\section{Ontario Forest Ranger SchOOL}

At the request of the Department of Lands and Forests four sessions of the ranger course have been conducted at the Ontario Forest Ranger School, University Forest, Dorset, Ontario. These have consisted of two sessions approximately a year apart for two different classes.

The general pattern followed has been to divide the men into groups with a member of the University staff in charge and a ranger instructor as assistant. The four major subjects covered have been telephony, silviculture and management, forest surveying, and estimating.

Based on the results so far obtained the course warrants longer instructional periods for the rangers; also the use of ranger assistants as instructors has merit. The men being developed as instructors were selected from those attending the first course and have proved to be thoroughly competent.

Comprises Forest Pathology and Forest Entomology which are taken in the Faculty of Arts. 